\title{
An Assessment of Knowledge Level of Apple Growers about Recommended Apple Spray Schedule in District Ganderbal, Kashmir, India
}

\author{
Rufaida Mir ${ }^{1}$, Mohd Afzal Beigh ${ }^{1}$, Zahoor Ahmad Shah ${ }^{1 *}$, Rekhi Singh ${ }^{2}$, \\ Jehangir Muzaffar Matoo ${ }^{1}$ and Mushtaq Ahmad Dar ${ }^{1}$ \\ ${ }^{I}$ Division of Agricultural Extension and Communication SKUAST-K, India \\ ${ }^{2}$ Programme Coordinator, KVK, Srinagar, India \\ *Corresponding author
}

\begin{abstract}
A B S T R A C T
Keywords

Apple growers,

Ganderbal, Kashmir,

Knowledge level,

Spray schedule

Article Info

Accepted:

12 December 2017

Available Online:

10 January 2018

The present study was conducted in district Ganderbal of Jammu and Kashmir with the size of 100 respondents. The district Ganderbal was purposively selected, because of the potentiality for the development of horticulture, and most of area of the district was under apple plantation. It was revealed that majority 61.00 per cent of the respondents possessed medium level of knowledge and respondents knowledge regarding, recommended chemical, its dose and time of spray was high for petal fall stage $(46.67 \%)$, fruit let stage $(42 \%)$, dormant stage $(40 \%)$ and pre-harvest stage $(29.34 \%)$. In case of recommended incompatibility of pesticides only 38.00 per cent of the respondents had the required knowledge. In case of overall knowledge level of the respondents about recommended apple spray schedule, majority 61.00 percent belonged to medium category of knowledge level, followed by high 21.00 per cent and 18.00 per cent belonged to low category.
\end{abstract}

\section{Introduction}

Apple is one of the most widely cultivated tree fruits. India is ranked as the (6th) sixth largest world's apple producing country and second largest country in area Apple is considered as one of the most important and widely grown fruit in temperate zones of the world with regard to its acreage, production, economic returns, high nutritive value and popularity. Apple tree is small and deciduous reaching 3 to 12 meter ( 9.0 to 39 feet) tall with broad often densely twiggy crown blossoms are produced in spring, simultaneously with budding of leaves. The fruit matures in autumn and is typically 5 to $9 \mathrm{cms}$ ( 2 to 3.5 inches) in diameter enriched with nutrients. The state of Jammu and Kashmir Comprising of temperature, cold arid and hilly areas are located in the North-Western region of the country and is capable of producing best quality of apple than rest of the states of the country. Nearly all of the Indian Apples are grown in three mountainous states of North India, Himachal Pradesh, Jammu and Kashmir and Uttaranchal where they are typically 
grown at an altitude of 4000 to 11000 feet (Shah et al., 2017).

Fruit industry is backbone of the economy of Jammu And Kashmir State. J\&K has remained the leading apple producer accounting for 64 per cent of the total production in the country. Apple mainly grown in Kashmir valley over an area of 1.417 lakh ha, with a production of 18.524 lakh tons (Anonymous, 2011). Varieties grown in Kashmir division: Ambri (Ambri Kashmiri), American Trel (American Apirogue), Delicious (Red Delicious), Maharaji (White Dotted Red), Hazaratbali (Benoni), Kesri (Cox's Orange Pippin) are some of the choicest varieties of apples.

In Jammu and Kashmir production constraints of apple in the state, among others, include a complex of key and secondary insect pests and diseases. Because of their impact upon the tree and fruit, ecological diversity and demand for almost blemish free crop the pests of pome fruits have received extensive study. Under Kashmir conditions, the most important pests attacking apple are: European red mite Pannonychus ulmi (Koch), Two spotted mite, Tetranychus urtica (Koch), Sanjose scale, Quadraspidiotus perniciosus (Cmstk), Woolly apple aphid, Eriosoma lanigerum (Hausmann), etc. Not only insect pests but also many diseases cause huge economic losses to apple. Principle diseases attacking are: Scab Venturia inequalis (Cke) Wint, Brown rot Sclerotinia fructigina, Sooty blotch Gloedes pomigena (Schw) Cloby \& Leaf spot Alternaria mali (Str) etc., (Anonymous, 1987b). A variety of pesticides have been employed to minimise the losses due to insect pests and diseases all over the world. Fungicides such as Carbendazim, Mancozeb, Myclobutanil and Fenarimol etc have been recommended against scab (Anonymous, 1987b and Sharma et al., 1991). Similarly Dimethoate, Phosphamidon, Ethion, Endosulphon, Quinolphos, Oxydemeton methyl, Malation and Carbaryl etc., has been recommended on apples against the key arthropod pests (Anonymous, 1987a and Hameed et al., 1985).

The weather is the greatest variable related to pest control. Warm and wet weather in the spring favours the development of apple scab, mildew, rots, and many other diseases. Under such conditions, it is necessary to spray more often in order to prevent infection. Dry, hot weather is often more favourable for insect population build-up, so it may be more difficult to control insects during hot, dry weather. There are many reasons for spraying apple trees multiple times during the year with right thing and at the right time. Spraying apple trees, to prevent fungal, bacterial diseases, to kill insects, to give nutrition directly to the leaves of the tree, to stimulate the trees own immunity from various diseases and to protect the fruit from sunburn as well as insects and other pathogens is a must.

During the past two decades, there has been a substantial increase in the use of pesticides in terms of both volume and value. The demand for agrochemicals depends upon the type of crops grown, farmer's knowledge about technologies and their profitability and also upon the availability, affordability and ease in accessing the input and output markets. Among different crops grown in Jammu \& Kashmir, apple cultivation is highly capitalintensive in terms of pest control measures. In the apple-growing belt of the valley, chemicals are being used indiscriminately without considering scientific recommendations. The choice of chemicals/brand preferences are steered by traders and market functionaries. The excessive/ indiscriminate use of pesticides not only increases the cost of apple cultivation but also results in many problems viz., problems related to human health, environmental contaminations, problems of pest resurgence, 
pesticide resistance etc. Moreover these problems are accentuated with the use of spurious chemicals and the existence of a chain of functionaries/unlicensed dealers between firms and farmers. The judicious application of pesticides, adoption of recommended commercial products, with other recommended technological interventions in apple should, therefore, be the concern of all stakeholders, researchers, and policy and decision makers. Knowledge refers to the factual information possessed by farmers regarding recommended apple spray schedule. English and English (1958) defined knowledge as a body of understood information possessed by an individual.

\section{Materials and Methods}

The present study was carried out in district Ganderbal of Jammu and Kashmir, and by following simple random sampling, 100 respondents were selected from 25 villages of four blocks. The data was elicited through personal interview method. The district Ganderbal was purposively selected, because of the potentiality for the development of horticulture, and most of area of the district was under apple plantation. Out of the four blocks of the district, village clusters were identified with higher areas under apple cultivation and out of those clusters a total of 25 villages were purposively selected for the study. Comprehensive lists of farmers engaged in apple cultivation from each village were framed in consultation with office of chief horticulture officer and HDOs' of the district.

Respondents were selected using proportionate sampling (taking area as auxiliary information) and ultimate unit of sampling (farmer) were selected randomly taking the sample size of 100 respondents, from whom data was collected. The knowledge test questions and answers were carefully framed with reference to the recommended spray schedule 2013-2014, formulated by the SKUAST (K). The answers were divided into three categories, 'full', 'partial' and 'no' knowledge elicited from the farmers were quantified by giving ' 2 ' score to 'full', ' 1 ' score to 'partial' and ' 0 ' to 'no' answers. Based on the response obtained, the knowledge level was quantified by using frequency and percentages. The respondents were classified into low, medium and high categories, using mean and standard deviation. Maximum score $=22$.

\section{Results and Discussion}

\section{Knowledge level of recommended apple spray schedule}

The data in the Table- 1 and Fig. 1 indicated that respondent's knowledge regarding recommended chemical, its dose and time of spray was high for petal fall stage $(46.67 \%)$, fruit let stage $(42 \%)$, dormant stage $(40 \%)$ and pre- harvest stage (29.34\%).

Regarding other recommended pesticide sprays, 25.67 and 25.34 per cent of the respondents had knowledge about green tip and fruit development I respectively, followed fruit development III (23.33\%), pink bud stage (23.00\%), fruit development II (21.67\%), fruit development IV (16\%) and post-harvest stage (1.67\%).

\section{Knowledge of incompatibility of pesticides}

In case of recommended incompatibility of pesticides only 38.00 per cent of the respondents had the required knowledge (Table-2). A perusal of the data in Table- 3 and Fig. 2 indicated that, overall knowledge level of the respondents about recommended apple spray schedule. Majority 61.00 per cent of the respondents had medium level of knowledge, followed by 21.00 per cent with high and 18.00 per cent with low level. 
Table.1 Knowledge level of recommended apple spray schedule n=100

\begin{tabular}{|l|l|c|c|c|c|c|}
\hline \multicolumn{1}{c|}{$\begin{array}{c}\text { S. Sprays } \\
\text { No. }\end{array}$} & $\begin{array}{c}\text { Full } \\
\text { Knowledge }\end{array}$ & $\begin{array}{c}\text { Partial } \\
\text { Knowledge }\end{array}$ & $\begin{array}{c}\text { No } \\
\text { knowledge }\end{array}$ & \multicolumn{2}{|c|}{ Total } \\
\hline 1. & Dormant & 60 & 0 & 40 & 120 & 40.00 \\
\hline 2. & Green tip & 35 & 7 & 58 & 77 & 25.67 \\
\hline 3. & Pink bud & 14 & 41 & 45 & 69 & 23.00 \\
\hline 4. & Petal fall & 56 & 28 & 16 & 140 & 46.67 \\
\hline 5. & Fruit let stage & 39 & 48 & 13 & 126 & 42.00 \\
\hline 6. & Fruit development I & 12 & 52 & 36 & 76 & 25.34 \\
\hline 7. & Fruit Development II & 7 & 51 & 42 & 65 & 21.67 \\
\hline 8. & Fruit Development III & 15 & 40 & 45 & 70 & 23.33 \\
\hline 9. & Fruit Development IV & 22 & 4 & 74 & 48 & 16.00 \\
\hline 10. & Pre-harvest & 39 & 10 & 51 & 88 & 29.34 \\
\hline 11. & Post-harvest & 0 & 5 & 95 & 5 & 1.67 \\
\hline & Total & $\mathbf{2 9 9}$ & $\mathbf{2 8 6}$ & $\mathbf{5 1 5}$ & $\mathbf{8 8 4}$ & $\mathbf{2 6 . 7 9}$ \\
\hline
\end{tabular}

Table. 2 Knowledge of incompatibility of pesticides $n=100$

\section{S. No. Incompatible pesticides}

1. Bitertanol $25 \mathrm{WP}(50 \mathrm{~g})+$ Chlorpyriphos $20 \mathrm{EC}(100 \mathrm{ml})$

2. $\quad$ Dodine $65 \mathrm{WP}(60 \mathrm{~g})+$ Chlorpyriphos $20 \mathrm{EC}(100 \mathrm{ml})$

3 Dodine $65 \mathrm{WP}(60 \mathrm{~g})+$ Dimethoate $30 \mathrm{EC}(100 \mathrm{ml})$

4. Dodine 65 WP $(60 \mathrm{~g})+$ Fenazaquin $10 \mathrm{EC}(40 \mathrm{ml})$

5. Captan 50 WP (300g)+ Chlorpyriphos 20 EC (100ml)

6. Captan 50 WP (300g) + Dicofol 18.5 EC (108 ml)

7. Captan $50 \mathrm{WP}(300 \mathrm{~g})+$ Fenazaquin $10 \mathrm{EC}(40 \mathrm{ml})$

\section{Per cent} 38

Table.3 Overall Knowledge level of respondents about recommended apple Spray schedule $n=100$

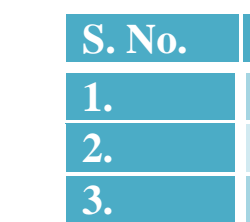

Mean $=8.84$

\begin{tabular}{|l|l|}
\hline Category & Per cent \\
\hline Low $(<$ Mean-SD = less than 5) & 18 \\
\hline Medium (Between Mean \pm SD $=5-13)$ & 61 \\
\hline High $(>$ Mean $+\mathrm{SD}=14$ and above $)$ & 21 \\
\hline
\end{tabular}

$$
\mathrm{SD}=4.83
$$

Categories of Knowledge level $(n=100)$

\begin{tabular}{|l|l|l|}
\hline S. No. & Category & Score \\
\hline 1. & Low & Low $(<$ Mean $-S D)$ \\
\hline 2. & Medium & Medium $($ Between Mean $\pm S D)$ \\
\hline 3. & High & High $(>$ Mean $+S D)$ \\
\hline
\end{tabular}


Recommended apple spray schedule

\begin{tabular}{|c|c|c|}
\hline S. No. & Tree stage & Recommended Chemicals \\
\hline 1. & Dormant & Diesel oil + Fish oil soap (Potash based) \\
\hline 2. & Green tip & $\begin{array}{l}\text { Mancozeb } 75 \mathrm{WP}(300 \mathrm{~g}) \text { or Zineb } 75 \mathrm{WP}(300 \mathrm{~g}) \\
\text { or Propineb } 75 \mathrm{WP}(300 \mathrm{~g})\end{array}$ \\
\hline 3. & Pink bud & $\begin{array}{l}\text { Dimethoate } 30 \mathrm{EC}(100 \mathrm{ml}) \text { or } \\
\text { Clothionidin } 50 \mathrm{WDG}(14 \mathrm{~g}) \text {, } \\
\text { Myclobutanil 10WP }(30 \mathrm{~g}) \text { or Dodine } 65 \mathrm{WP}(60 \mathrm{~g}) \text { or Dodine } 40 \mathrm{SC} \\
(70 \mathrm{ml}) \text { OR } \\
\text { Flusilazole } 40 \mathrm{EC}(20 \mathrm{ml}) \text { or } \\
\text { Bitertanol 25WP }(50 \mathrm{~g}) \text { or } \\
\text { Fenarimol 12EC }(40 \mathrm{ml})\end{array}$ \\
\hline 4. & Petal fall & 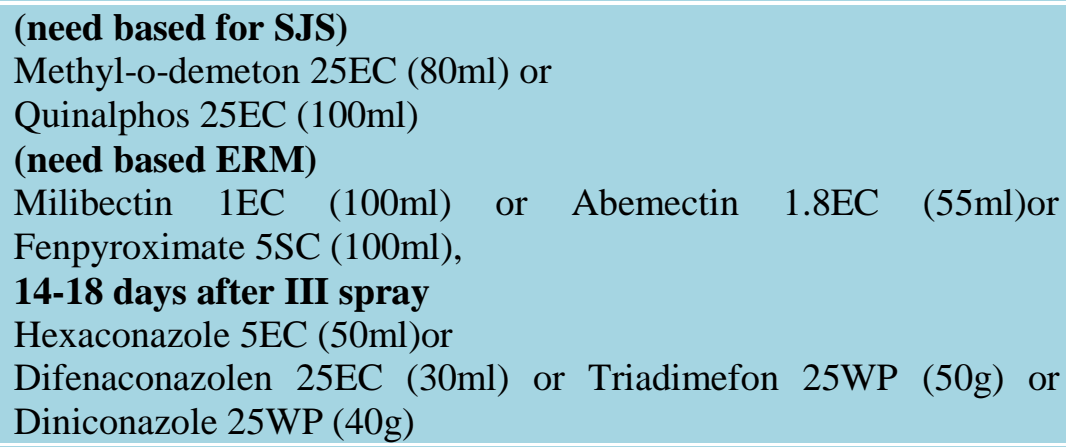 \\
\hline 5. & Fruit let stage & $\begin{array}{l}\text { Cholrpyriphos 20EC }(100 \mathrm{ml}) \text { or } \\
\text { Dimethoate } 30 \mathrm{EC}(1 \mathrm{ooml}) \text { or } \\
\text { Thiocloprid 240SC }(40 \mathrm{ml}) \\
\text { (need based ERM) } \\
\text { Dicofol 18.5EC }(108 \mathrm{ml}) \text { or Hexythaizox } 5 \mathrm{EC}(40 \mathrm{ml}) \text { or } \\
\text { Fenazaquin 10EC }(40 \mathrm{ml}) \text {, } \\
\text { 14-18 days after IV spray } \\
\text { Ziram } 80 \mathrm{WP}(200 \mathrm{~g}) \text { or Mancozeb } 75 \mathrm{WP}(300 \mathrm{~g}) \text { or Ziram } 27 \mathrm{~W} / \mathrm{V} \\
(600 \mathrm{ml}) \text { or Captan } 50 \mathrm{WP}(300 \mathrm{ml}) \text { or Propineb } 75 \mathrm{WP}(300 \mathrm{~g}) \text { or } \\
\text { Mancozeb flowable } 35 \mathrm{SL}(300 \mathrm{ml}) \text { or Zineb75WP }(300 \mathrm{~g}) \text { or Captan } \\
(70 \%)+\text { Hexaconazole }(5 \%) 75 \mathrm{WP}(50 \mathrm{~g}) \text { or Metiram }(55 \%)+ \\
\text { Pyraclostrobin }(5 \%) 60 \mathrm{WG}(100 \mathrm{~g})\end{array}$ \\
\hline 6. & Fruit development I & $\begin{array}{l}\text { (Need based for Bark and June beetles) } \\
\text { Clothianidin 50WDG }(14 \mathrm{~g}) \text { or } \\
\text { Quinalphos } 25 \mathrm{EC}(100 \mathrm{ml}) \text {, } \\
\text { (need based ERM) } \\
\text { Propargite 57EC }(88 \mathrm{ml}) \text { or Fenpyroximate } 5 \mathrm{SC}(100 \mathrm{ml}) \text {, } \\
\text { 14-18 days after V spray } \\
\text { Bitertanol } 25 \mathrm{WP}(50 \mathrm{~g}) \text { or Dithionon } 75 \mathrm{WP}(75 \mathrm{~g}) \text { or Triadimefon } \\
50 \mathrm{WP}(50 \mathrm{~g}) \text { or Penconazole } 10 \mathrm{EC}(50 \mathrm{~g}) \text { or Fenarimol } 12 \mathrm{EC}(40 \mathrm{ml}) \\
\text { or *Dodine } 65 \mathrm{WP}(60 \mathrm{~g})\end{array}$ \\
\hline 7. & Fruit Development II & $\begin{array}{l}\text { Chlorpyriphos 20EC }(100 \mathrm{ml}) \\
\text { or Methyl-o-demeton } 25 \mathrm{EC}(80 \mathrm{ml}) \\
\text { (For ERM) } \\
\text { Fenazaquin 10EC }(40 \mathrm{ml}) \text { or Spiromesifen 240SC }(40 \mathrm{ml}) \text {, } \\
\text { 14-18 days after VI spray } \\
\text { Hexaconazole 5EC } 50 \mathrm{ml}) \text { or Flusilazole } 40 \mathrm{EC}(20 \mathrm{ml}) \text { or }\end{array}$ \\
\hline
\end{tabular}




\begin{tabular}{|c|c|c|}
\hline & & Diniconazole 25WP (40g) \\
\hline 8. & Fruit Development III & 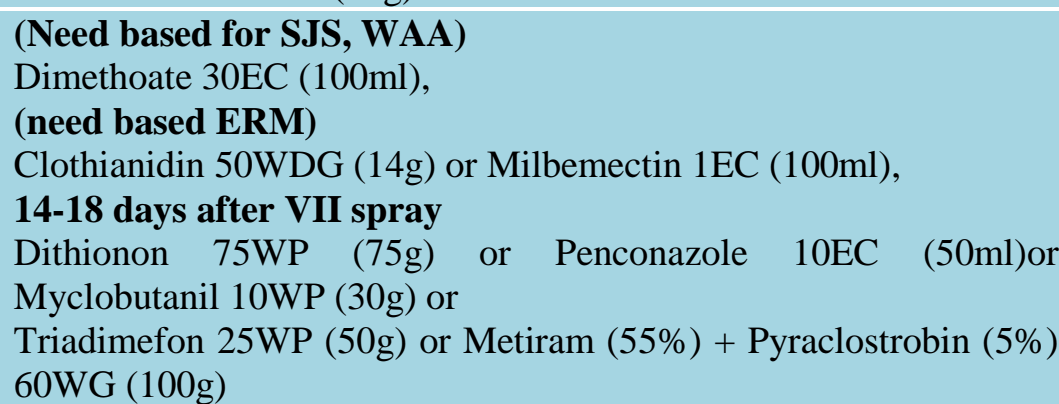 \\
\hline 9. & Fruit Development IV & $\begin{array}{l}\text { **14-18 days after VII spray } \\
\text { Difenaconazole 25EC }(30 \mathrm{ml}) \text { or } \\
\text { Bitertanol 25WP }(50 \mathrm{~g}) \text { or Fenarimol 12EC }(40 \mathrm{ml}) \text { or } * * * \text { Ziram } \\
80 \mathrm{WP}(200 \mathrm{~g}) \\
\text { or ***Propineb } 75 \mathrm{WP}(300 \mathrm{~g})\end{array}$ \\
\hline 10. & Pre-harvest & $\begin{array}{l}\text { ****25 days before harvest } \\
\text { Ziram } 80 \mathrm{WP}(200 \mathrm{~g}) \text { or Mancozeb } 75 \mathrm{WP}(300 \mathrm{~g}) \\
\text { or Ziram } 27 \mathrm{~W} / \mathrm{V}(600 \mathrm{ml}) \text { or } \\
\text { Captan } 50 \mathrm{WP}(300 \mathrm{~g}) \text { or Mancozeb flowable } 35 \mathrm{SL}(300 \mathrm{ml}) \text { or } \\
\text { Zineb } 75 \mathrm{WP}(300 \mathrm{~g}) \text { or Captan }(70 \%)+\text { Hexaconazole }(5 \%) 75 \mathrm{WP} \\
(50 \mathrm{~g})\end{array}$ \\
\hline 11. & Post-harvest & $\begin{array}{l}\text { (Need based for SJS, WAA) } \\
\text { Phosalone } 35 \mathrm{EC}(140 \mathrm{ml}) \text { or } \\
\text { Ethion } 50 \mathrm{EC}(100 \mathrm{ml}) \\
\text { (need based ERM) } \\
\text { Herbal }(200 \mathrm{ml}) \text { or Fenzaquin } 10 \mathrm{EC}(40 \mathrm{ml})\end{array}$ \\
\hline
\end{tabular}

Fig.1 Knowledge level of recommended sprays in the apple spray schedule

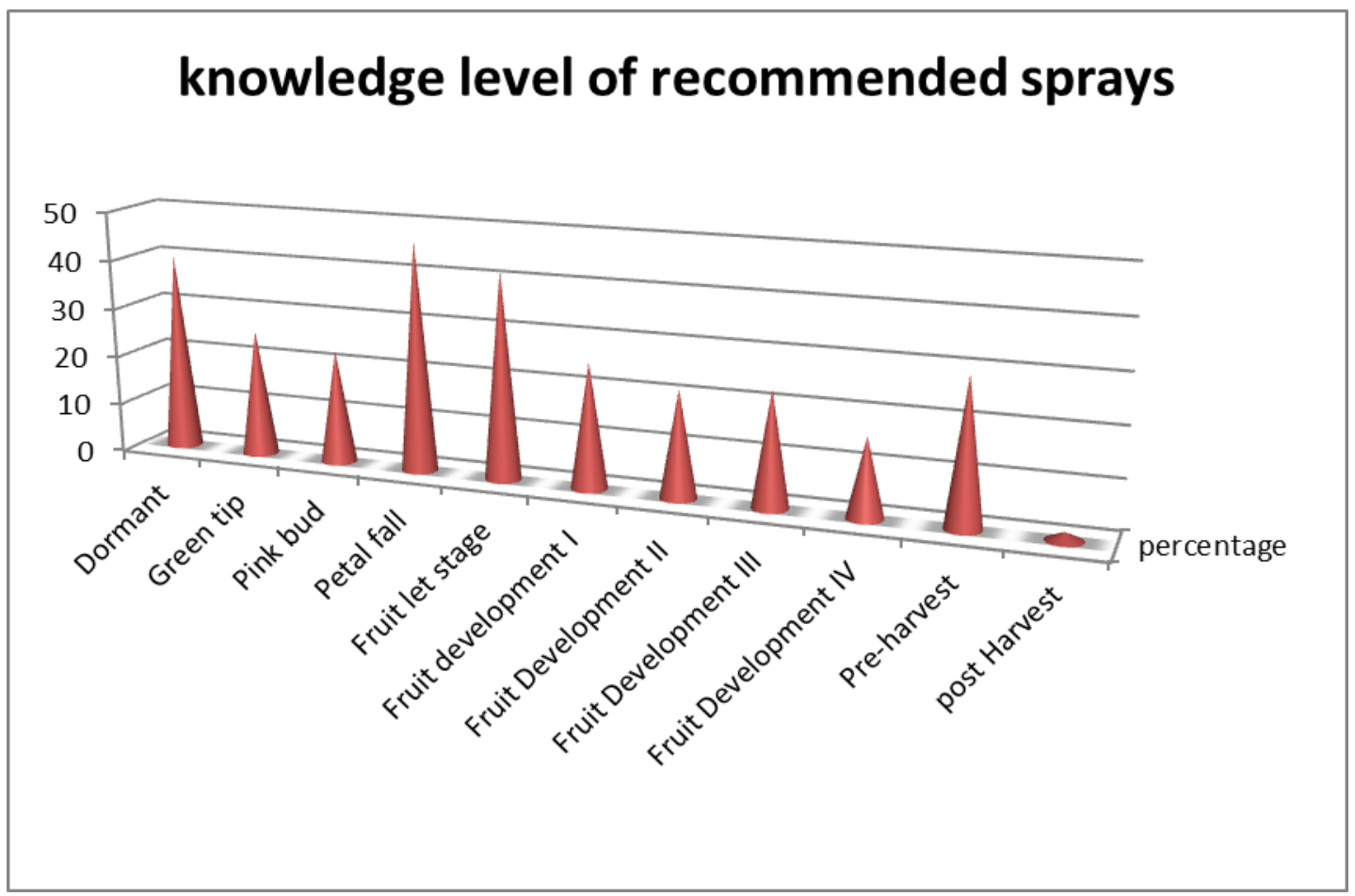


Fig.2 Overall knowledge level of the apple growers

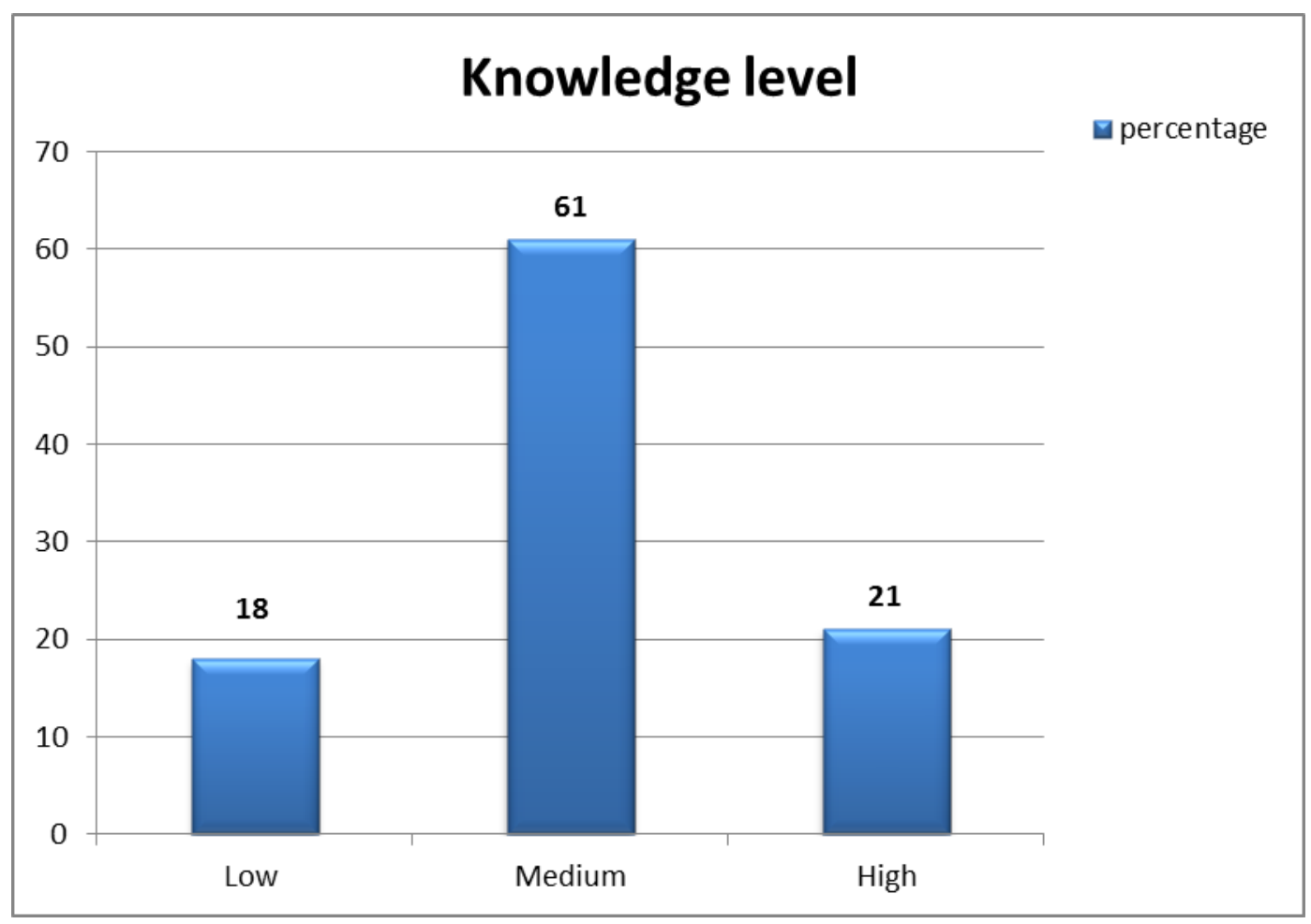

Knowledge level of apple growers about the recommended apple spray schedule

A perusal of the data in Table 2 indicated that, overall knowledge level of the respondents about recommended apple spray schedule. Majority of the respondents (61\%) had medium level of knowledge about recommended apple spray schedule followed by high $(21 \%)$ and low (18\%) knowledge level categories respectively. Apple spray schedule requires awareness of each recommendation. The present finding is in conformity with the findings of Reddy (1995) and Kumar (1996). The Table-3 reveals that the majority of the respondents had knowledge about recommended chemical, its dose and time of spray was high for petal fall stage $(46.67 \%)$, fruit let stage $(42 \%)$, dormant stage $(40 \%)$ and pre-harvest stage $(29.34 \%)$.

Adequate knowledge about recommended apple spray schedule is the pre-requisite for their pest management in apple. It is a fact that recommended practices are major contributing factors to yield. So, inadequate knowledge about recommended practices leads to their improper adoption. The farmers were not fully aware other recommended pesticide sprays, 25.67 and 25.34 per cent of the respondents had knowledge of about green tip and fruit development I respectively, followed by fruit development III (23.33\%), pink bud stage $(23.00 \%)$, fruit development II (21.67\%), fruit development IV (16\%) and post-harvest stage (1.67\%).

In addition only 38.00 per cent of the respondents had the required knowledge of recommended incompatibility of pesticides. In case of overall knowledge level of the respondents about recommended apple spray schedule, majority 61.00 percent belonged to medium category of knowledge level, followed by high 21.00 per cent and 18.00 per cent belonged to low category. 


\section{References}

Anonymous, 1987a. Check annual report, Division of Entomology SKUASTKashmir, Shalimar, Srinagar.

Anonymous, 1987b. Check annual report, Division Plant Pathology SKUASTKashmir, Shalimar, Srinagar.

Anonymous, 2011. Crop Wise Area and Production Estimates for Horticultural Crops. National Horticulture mission (NHM), pp. 2-3.

English, H.B. and English, A.C. 1958. A comparative dictionary of psycho analytical terms. Longermons, Greens and Co., New York.

Hameed, S.F., Kashyap, W.P. and Thakur, A.K. 1985. Residues of Finithrothion on apples and peaches and its toxicity to pest insects. Indian Journal of Entomology, 47: 206-210.

Kumar, S.R. 1996. A study on management of mango gardens by farmers in Krishnagiri taluk of Dharmapuri district, Tamil Nadu. M.Sc (Agri.) Thesis, Univ. Agric. Sci., Bangalore.

Reddy, SM.V. 1995. A study on knowledge and adoption of recommended mango cultivation practices among farmers of Kolar district. M.Sc (Agri) Thesis, Uni. Agric. Sci., Bangalore.

Shah, Z.A., Matoo, J.M., Mir, R., Dar M.A., and Beigh M.A. 2017. Knowledge level of recommended cultivation practices of apple growers in district Pulwama of J\&K: Journal of Pharmacognosy and Phytochemistry, 6(5): 2472-2474.

\section{How to cite this article:}

Rufaida Mir, Mohd Afzal Beigh, Zahoor Ahmad Shah, Rekhi Singh, Jehangir Muzaffar Matoo and Mushtaq Ahmad Dar. 2018. An Assessment of Knowledge Level of Apple Growers about Recommended Apple Spray Schedule in District Ganderbal, Kashmir, India. Int.J.Curr.Microbiol.App.Sci. 7(01): 1366-1373. doi: https://doi.org/10.20546/ijcmas.2018.701.166 